\title{
An Accounting Model of Carbon Footprint in Urban Distribution Systems
}

\author{
Lei Yang, Jiahui Hong \\ School of Economics and Commerce \\ South China University of Technology \\ Guangzhou, China \\ yang@scut.edu.cn
}

\begin{abstract}
With the rapid development of urban distribution system, the distribution mode is exhibiting the characteristic of irrational, and the carbon emissions of urban distribution have also become the focus of attention. This paper focuses on the research of the accounting model of carbon footprint in urban distribution system. Firstly, we analyze the process of urban distribution and then define the boundary of carbon footprint; secondly, make a systematic analysis on the emissions equipment, energy consumption and emissions type of various aspects of urban distribution; again introduce the carbon footprint calculation model with the framework of direct emissions and indirect emissions based on the characteristics of the enterprise management; then introduce the parameter of carbon emissions intensity to reflect the impact of unit income of urban distribution enterprise on the environment; finally, the example shows that the total amount of carbon emissions using the method can be applied to the parameter of carbon emissions intensity to evaluate the environmental benefits of urban distribution optimization mode.
\end{abstract}

Keywords—urban distribution; boundary definition; inventory analysis; carbon accounting

\section{INTRODUCTION}

\section{A. Background and Significance of the Research}

With the development of domestic economy and the improvement of people's living standards, and the promotion of the wave of mobile internet, the demand of urban distribution in recent years has increased dramatically. But in Beijing, Guangzhou and other developed cities, there are still some problems to be solved. Distribution vehicles are not standardized, and parking is difficult, and self distribution mode accounts for the main proportion.

Meanwhile, urban distribution is an industry with larger energy consumption, and its impact on urban environment is more direct and obvious, so it is necessary to integrate lowcarbon economy into the development of urban distribution, and study the carbon accounting method of urban distribution.

The research of low carbon economy and urban distribution mode is very important. From the point of view of social benefit, it can reasonably estimate the carbon emissions of urban distribution enterprises, reduce the emissions of

The sponsors are National Natural Science Foundation of China (71572058), Soft Science Program of Guangdong Province (2014A070703007 2015A070704008), and the Fundamental Research Funds for the Central Universities, SCUT (2015ZZ057). greenhouse gases, and create a good urban environment for people's life. From the point of view of economic efficiency, on one hand, it can provide a better urban distribution mode, which can reduce the investment in energy and reduce operating costs; on the other hand, it can improve the distribution efficiency and service level, and keep the competitive advantage of the enterprise.

\section{B. Related Study}

Through the review and analysis of domestic and foreign literature, the research of urban distribution has become a system, and the focus is on the vehicle routing optimization, distribution center location, sustainable development, distribution mode and so on. At the same time, the sustainable development of urban distribution is a hot research topic at present and in the future, and the low carbon economy is one of the sustainable development modes and the key research direction of sustainable development. In the last few years, the literature on low carbon and urban distribution is gradually increasing, but there is a lack of carbon accounting in urban distribution industry and it is the focus of this paper.

Browne et al. [1] summarized the negative effects of urban freight bringing to the city, as well as the measures to reduce these effects. Fernandez-Barcelo et al. [2] defined the social cost of urban distribution as the cost from the four parts of pollution emissions, noise, congestion and traffic accident. Maes et al. [3] predicted the economic and environmental impacts of bicycle distribution by simulation model and thought bicycle distribution was better than van distribution in terms of carbon emissions. Melo et al. [4] thought the coverage of small electric vehicles should be kept in the streets and it needed stakeholders to balance between low economic benefits and better environment benefits. Quak [5] thought the transportation company can improve its efficiency and sustainability through policy, technology and logistics solutions, and summarized the practice in logistics and technology in New Zealand and the European Union. Taniguchi et al. [6] studied the recent trends and innovations of urban logistics modeling from emissions, health care and megacity in order to better measure the environmental and social benefits of policy.

Dai [7] used carbon emissions as the optimization objective in the model of the vehicle routing problem in the 
express enterprises, and found it can reduce the time cost and carbon emissions. Hu et al. [8] put forward the construction idea of green distribution system, and in [9], they built multiobjective optimization model for urban distribution based on the traffic control and found the traffic control would increase distribution costs and environmental pollution. Jin [10] considered the carbon emission factor in the vehicle routing problem, and found that the hybrid vehicles were better than the single vehicles in the energy consumption and carbon emissions. Song [11] considered road congestion and carbon emissions in the study of periodic inventory and path problem and found the total cost can be reduced by an appropriate increase in the number of orders. Yang et al. [12] used life cycle assessment method to evaluate the impact of three urban distribution modes on the environment and thought third party logistics and joint distribution are worthy of promotion.

Overall, the study on the sustainable development of urban distribution is relatively comprehensive. Some focused on the impact of vehicles, technology, policy and other factors on environment and society, and others involved environmental benefits assessment, vehicle routing problem, etc. But the carbon accounting of urban distribution is at the exploratory stage, and need to do further research and analysis.

\section{THE ESTABLISHMENT OF THE MATHEMATICAL MODEL OF CARBON ACCOUNTING IN URBAN DISTRIBUTION}

\section{A. Boundary Definition of Carbon Footprint of Urban Distribution}

Currently companies involved in urban distribution are third-party logistics companies, enterprises' logistics departments or sub companies. The activity elements of general urban distribution are shown in TABLE I .

General process of urban distribution is in accordance with the order of stocking, storage, processing, sorting and picking, loading, transport and delivery service. In the process of urban distribution service, the enterprise consumes energy and produces carbon emissions. Therefore, the boundary of the carbon footprint of urban distribution should be limited in the range of the distribution process, whose starting point is stocking and ending point is delivery service.

TABLE I. URBAN DISTRIBUTION ACTIVITY ELEMENTS ANALYSIS

\begin{tabular}{|c|c|}
\hline $\begin{array}{l}\text { Activity } \\
\text { Element }\end{array}$ & Activity Description \\
\hline Stocking & $\begin{array}{l}\text { According to distribution requirements, finish cargo } \\
\text { collection, receiving, inspection and other management. }\end{array}$ \\
\hline Storage & $\begin{array}{l}\text { Reserve and Temporary storage. Reserve is to ensure } \\
\text { distribution resources to meet requirements, and emporary } \\
\text { storage is to coordinate the time of picking and delivery. }\end{array}$ \\
\hline Processing & $\begin{array}{l}\text { Content is flexible, such as simple packaging, labeling, etc., } \\
\text { depending on customer requirements. }\end{array}$ \\
\hline $\begin{array}{l}\text { Sorting and } \\
\text { picking }\end{array}$ & $\begin{array}{l}\text { Based on customer orders, remove and pick goods from } \\
\text { storage spaces, and move to staging area or shipping zone. }\end{array}$ \\
\hline Loading & $\begin{array}{l}\text { For cargo whose distribution amount can't achieve vehicle } \\
\text { effective load rate, consider using one vehicle. }\end{array}$ \\
\hline Transport & $\begin{array}{l}\text { The purpose is delivery, distance is short, transportation } \\
\text { tools are vehicles and the scale of cargo is small. }\end{array}$ \\
\hline $\begin{array}{l}\text { Delivery } \\
\text { service }\end{array}$ & $\begin{array}{l}\text { Coordinate the problem of how to receive the goods after } \\
\text { goods are shipped to the destination. }\end{array}$ \\
\hline
\end{tabular}

\section{B. Inventory Analysis of Carbon Footprint in Urban Distribution}

From the aspects of energy consumption and emissions in the process of urban distribution, the energy consumption of stocking is fuel and electricity, supporting the normal use of testing and storage equipments (such as forklifts, barcode scanners etc.); storage needs to do dehumidification, ventilation, insulation, monitoring, etc., so energy consumption is electricity with indirect emissions; If using automated equipments, processing would have electricity consumption and indirect emissions; sorting and picking use automatic sorting machines, belt conveyor etc. to achieve fast automatic sorting, with electricity consumption and indirect emissions; loading relies on experience, and energy consumption and carbon emissions are almost negligible; energy consumption of transport vehicles is mainly fuel and is partly electricity; POS machines, forklifts, and other ancillary equipments used in delivery service mainly consume electricity. In addition, electricity consumption of lighting in distribution center to ensure distribution quality can't be ignored, resulting in indirect emissions. Specific content is showed in TABLE II .

Through the detailed analysis of carbon footprint in urban distribution system, we find there are direct carbon emissions from fuel combustion and indirect carbon emissions from electricity consumption, and the quantity of emissions equipment is large.

TABLE II. INVENTORY OF CARBON FOOTPRINT IN URBAN DISTRIBUTION

\begin{tabular}{|c|c|c|c|c|c|}
\hline \multirow{2}{*}{$\begin{array}{l}\text { Activity } \\
\text { Element }\end{array}$} & \multirow{2}{*}{$\begin{array}{l}\text { Emissions } \\
\text { Equipment }\end{array}$} & \multirow{2}{*}{$\begin{array}{c}\text { Energy } \\
\text { Consumption } \\
\text { And Emissions } \\
\text { Type }\end{array}$} & \multicolumn{3}{|c|}{$\begin{array}{c}\text { Main Greenhouse } \\
\text { Gas Type }\end{array}$} \\
\hline & & & $\mathrm{CO}_{2}$ & $\mathrm{CH}_{4}$ & $\mathrm{~N}_{2} \mathrm{O}$ \\
\hline Stocking & $\begin{array}{l}\text { Forklifts, barcode } \\
\text { scanners etc. }\end{array}$ & $\begin{array}{l}\text { Fuel and } \\
\text { electricity, direct } \\
\text { and indirect } \\
\text { emissions }\end{array}$ & $\sqrt{ }$ & $\sqrt{ }$ & $\sqrt{ }$ \\
\hline Storage & $\begin{array}{l}\text { Dehumidification, } \\
\text { ventilation, } \\
\text { insulation, } \\
\text { monitoring and } \\
\text { other devices }\end{array}$ & $\begin{array}{l}\text { Electricity, } \\
\text { indirect } \\
\text { emissions }\end{array}$ & $\sqrt{ }$ & & \\
\hline Processing & $\begin{array}{l}\text { Automated } \\
\text { equipments }\end{array}$ & $\begin{array}{l}\text { Electricity, } \\
\text { indirect } \\
\text { emissions }\end{array}$ & $\sqrt{ }$ & & \\
\hline $\begin{array}{l}\text { Sorting } \\
\text { and } \\
\text { picking }\end{array}$ & $\begin{array}{lr}\text { Automatic } & \text { sorting } \\
\text { machines, } & \text { belt } \\
\text { conveyor etc. }\end{array}$ & $\begin{array}{l}\text { Electricity, } \\
\text { indirect } \\
\text { emissions }\end{array}$ & $\sqrt{ }$ & & \\
\hline Loading & Computers, etc. & $\begin{array}{l}\text { Electricity, } \\
\text { indirect } \\
\text { emissions(almost } \\
\text { negligible) }\end{array}$ & $\sqrt{ }$ & & \\
\hline Transport & Transport vehicles & $\begin{array}{l}\text { Fuel and } \\
\text { electricity, direct } \\
\text { and indirect } \\
\text { emissions }\end{array}$ & $\sqrt{ }$ & $\sqrt{ }$ & $\sqrt{ }$ \\
\hline \multirow[t]{2}{*}{$\begin{array}{l}\text { Delivery } \\
\text { service }\end{array}$} & $\begin{array}{l}\text { Phones, POS } \\
\text { machines, forklifts, } \\
\text { and other ancillary } \\
\text { equipments }\end{array}$ & $\begin{array}{l}\text { Electricity, } \\
\text { indirect } \\
\text { emissions }\end{array}$ & $\sqrt{ }$ & & \\
\hline & $\begin{array}{l}\text { Lighting } \\
\text { equipments }\end{array}$ & $\begin{array}{l}\text { Electricity, } \\
\text { indirect } \\
\text { emissions }\end{array}$ & $\sqrt{ }$ & & \\
\hline
\end{tabular}


For the type of greenhouse gas emissions, according to Appendix II of "Provincial Greenhouse Gas Inventories Compilation Guide", carbon dioxide, methane and nitrous oxide from fuel combustion need to be the inclusion of carbon emissions inventory.

\section{Urban Distribution Carbon Footprint Accounting Model}

The research on the greenhouse gas emission inventory report is relatively comprehensive, and provides reference for the accounting of urban distribution carbon footprint. Referring to the methodology of "2006 IPCC Guidelines for National Greenhouse Gas Inventories”, the accounting model of urban distribution carbon footprint uses the method of emission factors.

$$
m=\sum \sum\left(D_{f} \times C_{f} \times E_{f, l} \times 10^{-6} \times G_{l}\right)+A \times B
$$

Here, $m$ represents the total emissions of greenhouse gases in urban distribution; $D_{f}$ represents the consumption of fuel $f$ in the statistical period of the enterprise, which is referred to as the activity data, and the data is based on the actual measurement; $C_{f}$ represents the low calorific value of fuel $f$, and the reference values are showed in TAIBLE $E_{f, l}$ represents the greenhouse gas emissions factor corresponding to the fuel $f$, and the reference values are showed in TABLE III; $G_{l}$ represents the global warming potential of greenhouse gases, a measure of the relative strength of greenhouse gases, and the reference values are showed in TMBLE $A$ represents the amount of electricity the enterprise consumed in the statistical period of the enterprise, which is referred to as the activity data, and the data is based on the actual measurement; $B$ represents purchased electricity emission factor, and the reference values are showed in TABLE V.

If again analyze the process of building accounting model of urban distribution carbon emissions, we can find this part is not closely related to carbon footprint boundary definition and emission inventory. Actually it's just from another angle to account carbon emissions, and the collection of activity data still needs to be closely linked to the carbon emissions inventory. They are key aspects during activity data collection to record what energy each device consumed and how much consumed. Enterprises may collect activity data preliminarily in the form similar to TABLE VI. Then aggregate activity data in accordance with the energy category, and carry out carbon accounting according to (1).

With the accounting model, it is not representative to measure environmental benefits of urban distribution by

TABLE III. AVERAGE CALORIFIC VALUE OF FUEL AND REFERENCE VALUE OF EMISSION FACTOR

\begin{tabular}{|c|c|c|c|c|}
\hline Fule Type & $\begin{array}{c}\text { Average } \\
\text { Calorific } \\
\text { Value } \\
(\mathbf{M J} / \mathrm{t}) \\
\end{array}$ & $\begin{array}{c}\mathrm{CO}_{2} \\
\text { Emission } \\
\text { Factor }^{\mathbf{b}} \\
\left.\text { (gCO }_{2} / \mathrm{MJ}\right) \\
\end{array}$ & $\begin{array}{c}\mathrm{CH}_{4} \\
\text { Emission } \\
\text { Factor }^{\mathrm{b}} \\
\text { (gCH } 4 / \mathbf{M J}) \\
\end{array}$ & $\begin{array}{c}\mathrm{N}_{2} \mathrm{O} \\
\text { Emission } \\
\text { Factor }^{\mathrm{b}} \\
\left(\mathrm{gN}_{2} \mathrm{O} / \mathrm{MJ}\right) \\
\end{array}$ \\
\hline Gasoline & $43070^{\mathrm{a}}$ & 67.9 & 0.033 & 0.0032 \\
\hline Diesel fuel & $42652^{\mathrm{a}}$ & 72.6 & 0.0039 & 0.0039 \\
\hline $\begin{array}{c}\text { Liquefied } \\
\text { natural gas }\end{array}$ & $46900^{\mathrm{b}}$ & 62.9 & 0.092 & 0.003 \\
\hline
\end{tabular}

a Data is from "General Principles for Calculation of the Comprehensive Energy Consumption". b Data is from "2006 IPCC Guidelines for National Greenhouse Gas Inventories”.
TABLE IV. VALUE OF GLOBAL WARMING POTENTIAL

\begin{tabular}{|c|c|c|c|}
\hline Greenhouse Gas Type & $\mathbf{C O}_{2}$ & $\mathbf{C H}_{\mathbf{4}}$ & $\mathbf{N}_{\mathbf{2}} \mathbf{O}$ \\
\hline Global warming potential $^{\mathrm{C}}$ & 1 & 25 & 298 \\
\hline
\end{tabular}

TABLE V. 2010-2014 PURCHASED ELECTRICITY EMISSION FACTOR

\begin{tabular}{|c|c|c|c|c|c|}
\hline Year & $\mathbf{2 0 1 0}$ & $\mathbf{2 0 1 1}$ & $\mathbf{2 0 1 2}$ & $\mathbf{2 0 1 3}$ & $\mathbf{2 0 1 4}$ \\
\hline $\begin{array}{c}\text { Electricity emission } \\
\text { factor }^{\mathrm{d}}\left(\mathrm{tCO}_{2} \mathrm{e} / \mathrm{MWh}\right)\end{array}$ & 0.9762 & 0.9489 & 0.9344 & 0.9223 & 0.9183 \\
\hline
\end{tabular}

TABLE VI. URBAN DISTRIBUTION ACTIVITY DATA COLLECTION FORM

\begin{tabular}{|c|c|c|c|c|}
\hline No. & $\begin{array}{c}\text { Distribution } \\
\text { Activity }\end{array}$ & $\begin{array}{c}\text { Emissions } \\
\text { Equipment }\end{array}$ & $\begin{array}{c}\text { Energy } \\
\text { Type }\end{array}$ & $\begin{array}{c}\text { Activity } \\
\text { Data }\end{array}$ \\
\hline 1 & & & & \\
\hline 2 & & & & \\
\hline$\cdots$ & & & & \\
\hline
\end{tabular}

comparing carbon emissions in different statistical years. A better approach is to introduce annual turnover of distribution companies to build the new indicator: urban distribution carbon intensity (UDCI). This indicator is the ratio of the total carbon emissions and annual turnover, and is used to explain the environment impact per income of the urban distribution company. The indicator is determined by (2), where UDCI represents urban distribution carbon intensity, $m$ represents the total emissions of greenhouse gases in urban distribution, $T$ represents annual turnover of the urban distribution enterprise.

$$
U D C I=m / T
$$

\section{CASE STUDY}

As a well-run distribution company in Guangzhou, in the early time the distribution mode of the enterprise was direct mode of point-to-point. In 2014, the company became the pilot enterprise of Guangzhou urban distribution, and in the agreement with the customers, it gradually implemented centralized distribution, joint distribution and other advanced distribution mode. The aggregated results of annual turnover and activity data of the enterprise in the year of 2013 and 2014 are shown in TABLE VII.

According to (1) and (2), the total amount of carbon emissions in urban distribution of the enterprise in 2013 is 1190.25 tons of carbon dioxide equivalent, and urban

TABLE VII. AGGREGATED FORM OF ANNUAL TURNOVER AND ACTIVITIES

\begin{tabular}{|c|c|c|c|c|}
\hline \multirow{2}{*}{ No. } & \multirow{2}{*}{ Emissions Equipment } & \multirow{2}{*}{$\begin{array}{l}\text { Energy } \\
\text { Type }\end{array}$} & \multicolumn{2}{|c|}{ Activity Data } \\
\hline & & & 2013 & 2014 \\
\hline 1 & $\begin{array}{l}\text { Inter- combustion forklifts, } \\
\text { van I }\end{array}$ & Diesel fuel & $308.35 t$ & $354.43 \mathrm{t}$ \\
\hline 2 & Van II & Gasoline & $49.42 \mathrm{t}$ & $53.72 \mathrm{t}$ \\
\hline 3 & $\begin{array}{l}\text { Barcode scanners, } \\
\text { dehumidifiers, ventilation } \\
\text { and monitoring equipments, } \\
\text { automatic sorting machines, } \\
\text { computers, POS machines, } \\
\text { lighting equipments }\end{array}$ & Electricity & $\begin{array}{l}76.49 \\
\text { MWh }\end{array}$ & $\begin{array}{l}89.99 \\
\text { MWh }\end{array}$ \\
\hline 4 & \multicolumn{4}{|c|}{$\begin{array}{l}\text { Annual turnover in 2013: } 613.53\left(10^{4} \mathrm{RMB}\right) \text {; Annual turnover in 2014: } \\
\left.\text { 708.55(10 }{ }^{4} \mathrm{RMB}\right) \text {. }\end{array}$} \\
\hline
\end{tabular}
DATA IN 2013 AND 2014

c Data is from Intergovernmental Panel on Climate Change Fourth Assessment Report $\mathrm{d}$ Data is from Southern $\mathrm{EF}_{\mathrm{OM}}$ of "Chinese regional electricity grid baseline emission factor". 
distribution carbon intensity is 1.94 tons of carbon dioxide equivalent per ten thousand RMB; the total amount of carbon emissions in urban distribution of the enterprises in 2014 is 1360.41 tons of carbon dioxide equivalent, and urban distribution carbon intensity is 1.92 tons of carbon dioxide equivalent per ten thousand RMB.

As you see, the total amount of carbon emissions in urban distribution of the enterprises in 2014 is higher than that in 2013. But due to the change of urban distribution mode, carbon emission intensity has a small decline of $1.03 \%$, indicating the new urban distribution mode has a positive impact on the environment.

Through the case analysis, the model this paper constructs can make a comprehensive and reasonable calculation of the carbon footprint of urban distribution. More importantly, as a tool, the model can measure the greenhouse gas emissions before and after the optimization of urban distribution mode, and with the help of the indicator of urban distribution carbon intensity, it can quantitatively represent and compare the environmental benefit of different urban distribution mode.

\section{CONCLUSION}

As an important part of the logistics industry, urban distribution enterprises consume much fuel and electricity, and produce a lot of greenhouse gas emissions, which is one of the important sources of urban carbon footprint. Therefore, this paper focuses on the establishment of carbon accounting model of urban distribution.

The first step is a detailed analysis of urban distribution process. Stocking, storage, processing, sorting and picking, loading, transport and delivery service are all sources of carbon emission. Define urban distribution carbon footprint boundary, in order to better carry out energy conservation work in the control of the enterprise. In the process of emission inventory analysis, the energy consumption, emissions equipments and emissions type of every link are analyzed. Next, drawing on relevant researches, the paper builds carbon accounting model consisting of direct and indirect emissions, and thinks that activity data collection should be based on the emissions inventory analysis. Besides, the indicator of urban distribution carbon intensity is introduced, measuring the change of the impact of urban distribution optimization scheme on the environment. Finally, through case analysis, it shows that the carbon footprint calculation method in this paper can help enterprises to better calculate the total amount of carbon emissions, and the result can be used to the parameter of urban distribution carbon intensity. It provides quantitative indicator for the enterprise to measure the pros and cons of its optimization scheme and gradually guides the urban distribution companies to voluntarily carry out carbon disclosed.

In addition, urban distribution mode optimization involves the recombination of the distribution activity elements, and it is consistent with the process of carbon footprint calculation of urban distribution. So it is the key content of the follow-up study that how to combine carbon footprint calculation model of urban distribution and urban distribution mode optimization.

\section{References}

[1] M. Browne, J. Allen, T. Nemoto, D. Patier and J. Visser, Reducing social and environmental impacts of urban freight transport: a review of some major cities, vol. 39. Procedia-Social and Behavioral Sciences, 2012, pp. 19-33.

[2] I. Fernandez-Barcelo and J. M. Campos-Cacheda, Estimate of social and environmental costs for the urban distribution of goods. Practical case for the city of Barcelona, vol. 39. Procedia-Social and Behavioral Sciences, 2012, pp. 818-830.

[3] J. Maes and T. Vanelslander, The use of bicycle messengers in the logistics chain, concepts further revised, vol. 39. Procedia-Social and Behavioral Sciences, 2012, pp. 409-423.

[4] S. Melo, P. Baptista and Á. Costa, Comparing the use of small sized electric vehicles with diesel vans on city logistics, vol. 111. ProcediaSocial and Behavioral Sciences, 2014, pp. 1265-1274.

[5] H. J. Quak, Improving urban freight transport sustainability by carriersbest practices from the Netherlands and the EU project CityLog, vol. 39. Procedia-Social and Behavioral Sciences, 2012, pp. 158-171.

[6] E. Taniguchi, R. G. Thompson and T. Yamada, Recent trends and innovations in modelling city logistics, vol. 125. Procedia-Social and Behavioral Sciences, 2014, pp. 4-14.

[7] C. Dai, Distribution path selection of courier companies study considering carbon emissions. China: Southwest Jiaotong University, 2014.

[8] Y. Hu, J. Shen and A. Huang, Study on establishing urban green logistics and distribution system, vol. 15. China: Logistics technology, 2012, pp. 56-59.

[9] Y. Hu, J. Shen and A. Huang, Multi-objective optimization for city distribution under urban freight restriction, vol. 6. China: Journal of transportation systems engineering and information technology, 2012, pp. 119-125.

[10] F. Jin, Vehicle routing optimization theory and methods based on lowcarbon economy perspective. China: Central South University, 2013.

[11] L. Song, Research on agriculture-supermarket direct sending low-carbon period inventory-routing optimization model considering traffic congestion. China: Northeastern University, 2013.

[12] J. Yang, J. Guo and S. Ma, Environmental impact assessment of urban logistics distribution system, vol. 12. China: Urban problems, 2012, pp. 37-41. 